\title{
Pathogen Identification and Evaluation of Chickpea Varieties for Resistance Against the Pathogens in West Shewa, Oromia Regional State, Ethiopia
}

\author{
Daniel Assfaw*1 Thangavel Selvaraj ${ }^{2} \quad$ Gezahegn Getaneh $^{2}$ \\ 1.Bonga University College of Agriculture and Natural Resource, Department of Plant Science, P.O. Box 334, \\ Bonga Ethiopia \\ 2.Ambo University College of Agriculture and Veterinary Science, Department of Plant Science
}

\begin{abstract}
Chickpea (Cicer arietinum L) is one of the economically important grain legume crops in Africa particularly in Ethiopia which widely grown in marginal soils and usually as rotational crops in highland and semi-highland regions of the country and also as a source of cash to the farmers and foreign currency in Ethiopia. However, its production is affected by many pest and diseases. Among them wilt or root rot diseases are considered as the major problems in chickpea production. Therefore, the present study was conducted to identify chickpea wilt or root rot causing pathogens and evaluate of chickpea varieties resistance against identified pathogens in West Shewa, Oromia regional state, Ethiopia. The pathogenicity test revealed that three fungal pathogens, Fusarium oxysporum, Fusarium solani and Rhizoctonia bataticola were identified as wilt/root rot causing pathogens. The percentage frequency of occurrence of Fusarium oxysporum, Fusarium solani and Rhizoctonia bataticola regardless of the districts were 50.7\%, 26.76\% and $14.08 \%$, respectively. Among seven chickpea varieties, host resistance were evaluated against the identified wilt /root rot causing fungal pathogens, the variety, Arerti was the only resistant to all identified wilt causing pathogenic isolates. The varieties, Arerti and Shasho were resistant and Habru was moderately resistant reaction to Fusarium oxysporum. But local and Dz-10-4 cultivars were found to be highly susceptible. The cultivars, Arerti, Acos dube and Dz-10-4 were found to be resistant and Shasho and Chefe were moderately resistant to Rhizoctonia bataticola. Except Arerti variety, all inoculated varieties were susceptible to Fusarium solani isolate. Only local variety was highly susceptible to all identified pathogenic isolates. The remaining varieties were susceptible to tested pathogenic isolates with varying degrees. Therefore, from the artificial inoculation test, resistance of chickpea varieties to specific isolates could be further deployed for sustainable wilt or root rots management. Further, the effective and feasible integrated management options need to be developed on chickpea wilt/root rot diseases in the country.
\end{abstract}

Keywords: Chickpea Wilt or Root rots Pathogens, isolation, varieties, host resistance.

DOI: $10.7176 /$ ALST/73-04

Publication date: April $30^{\text {th }} 2019$

\section{INTRODUCTION}

Ethiopia is the largest producer of chickpea in Africa, accounting for about $46 \%$ of the continent's production during 1994-2016. Chickpea is the second most important cool season food legume crop next to common bean (Phaseolus vulgaris L.) followed by field pea (Pisum sativum L.) and third in production worldwide (Diapari et al., 2014). Currently, it is one of the widely cultivated crops at the global level on 13.5 million hectares of area with a production 13.1 million tons (FAOSTAT, 2016).

In Ethiopia, crops are grown annually on approximately 7.9 million hectares, which is appropriate to pulses. Pulse crops have diverse roles to play in the country and rank a second food after cereals and occupy about $17.7 \%$ of the total cultivated areas and contribute about $12 \%$ of the total production (CSA, 2016). Ethiopia shares $2 \%$ among the most chickpea producing countries next to India (73.3\%), Turkey (8\%) and Pakistan (7.3\%). The total annual average during 1999-2008 chickpea production is estimated at about 173 thousand tons (Menale et al., 2009). The national average yield of chickpea in Ethiopia under farmers' production condition remains less than 2.0 tons ha $^{-1}(\mathrm{CSA}, 2017)$. A number of limiting factors contribute to low productivity of chickpea. The primary cause of low yields in chickpea is its susceptibility to a number of biotic and abiotic stresses.

The crop suffers from serious diseases that affect it in all growth stages. The major threats to the production of the chickpea crops in Ethiopia are the diseases of fungal origin particularly Fusarium wilts and root rots diseases (Tadesse et al., 1998). Wilt pathogens are a serious problem especially in the rain fed area. (Jalali and Chand, 1992). As chickpea is a rain fed crop and is grown under low input conditions, continuous seed treatment with fungicides are not possible (Chaudhry et al., 2006). Therefore, the importance of resistant cultivars is an established fact recognized by the researchers. Many sources of resistance to wilt pathogen, Fusarium oxysporum f. sp. ciceri have been reported mainly based either on field observations, during natural epidemics or on artificial inoculation either in the field or green house. Host resistance, however does not persist as varieties 
presumed to be wilt resistant failed, either as a result of genetic breakdown or a change in the virulence of the pathogen (Nene, 1987; Jamil et al., 2010). Since the host plant resistance provides the economical and the most practicable control of diseases, therefore, a reliable screening procedure is required for incorporating durable resistant in varieties. A little information is available in germplasm evaluated for dual resistance against wilt/root rot pathogens in Western Showa, Ethiopia. Therefore, the present study was undertaken with the following objectives to identify the chickpea wilt/root rots causing pathogens and to evaluate the resistance of chickpea varieties against the identified wilt/root rot pathogens under glasshouse conditions.

\section{MATERIALS AND METHODS}

\section{Description of the study area}

The laboratory and glasshouse studies were conducted in Ambo Plant Protection Research Centre (APPRC). Ambo is located $120 \mathrm{~km}$ west of Addis Ababa at $8^{\circ} 98^{\prime}$ South latitude and $37^{\circ} 83^{\prime}$ North longitude. It has a total geographical area of 83,598.69 sq. km., with elevation ranging from 1380-3300 m. a. s. 1. Annual rainfall ranged from $900-1100 \mathrm{~mm}$ and temperature ranged from $10-27^{\circ} \mathrm{C}$, with an average of $18^{\circ} \mathrm{C}$. The soil type of the study site is vertisol with a $\mathrm{pH}$ value of 6.8 .

\section{Diseased plant samples collection}

The diseased plant samples were collected and randomly selected from 70 cultivated fields. From these fields, 23 diseased wilted plant samples were collected per field. Only samples taken from 40 fields were developed as a pure culture in artificial media. A sample of wilted/root rot diseased plants were uprooted and kept separately into polythene bags and placed inside the ice box of about $4^{0} \mathrm{C}$ and brought to Ambo Plant Protection Research Center (APPRC) for identification and further test. The samples were labeled with date of collection, locality and altitude and chickpea cultivar names. From each field, wilted, dead and plant exhibiting chlorosis were observed. General symptoms observed were yellowing of leaves, chlorosis, root rot, collar rot, completely wilted and dead plants. When the infected plants were uprooted, vascular tissue discoloration was observed in most of them.

\section{Isolation of the pathogens}

The plant part (roots) was thoroughly washed under tap water and cut into pieces of disease part along with healthy tissue and surface sterilized using $70 \%$ ethyl alcohol. These pieces were placed aseptically on sterilized Potato Dextrose Agar (PDA) media separately on Petri plates. All of the samples were also cultured on Oat Meal Agar (OMA) (20 g oatmeal, $5 \mathrm{~g}$ of sucrose, and $20 \mathrm{~g}$ of agar and $1000 \mathrm{ml}$ of distilled water) and Sabouraud's Agar Medias (Peptone $10 \mathrm{~g}$, dextros 40g, agar 20g and distilled water 1000ml). Incubate the petri-dishes under alternating cycles of $12 \mathrm{~h}$ near Ultra-Violet (UV) light and $12 \mathrm{~h}$ darkness for at $25^{\circ} \mathrm{C}$ for $48 \mathrm{~h}$ for sporulation. After five days of incubation at $25^{\circ} \mathrm{C}$, colonies of wilt fungal pathogens were transferred to fresh PDA Medias. Pure culture of wilt pathogens were done by transferring of a pinch of mycelium on sterilized PDA medium in Petri plates and incubated. Sub culturing was done till distinct pure culture was obtained. The isolated pathogens frequency was calculated using formula proposed by Shivendra Pathak, (2016) to determine the percentage of occurrence of the different pathogens in the culture.

Percentage of occurrence $=\mathrm{X} / \mathrm{N} \times 100 \%$

$\mathrm{X}=$ total number of each organisms in all the samples

$\mathrm{N}=$ total number of the entire organisms in all the samples

\section{Isolation of chickpea wilt/root rots causing pathogens}

The identification of the fungi was based on the cultural characteristics, mainly on the growth patterns and pigmentation. Further microscopic examinations were carried out for mycelial and conidia structures based on using identification manual of illustrated genera of imperfect fungi (Barnett and Hunter, 1998). The morphological characteristics was carried out by taking small amount of mycelium from ten days old pure culture plates using a sterile needle and transferred on to a cleaned glass slide. The culture was taken from five different positions of the culture plate, four from adjacent side and one from middle. The mycelium was stained with $0.1 \%$ lacto phenol cotton blue and observed under compound microscope.

\section{Mass multiplication of the pathogens for inoculation}

Inoculum of the fungus was prepared by soaking sorghum grains in tap water overnight and then as surface dried by spreading on paper towels in laboratory (Figure 6). Surface dried seeds were put into conical flasks at $250 \mathrm{~g}$. These flasks were autoclaved at $15 \mathrm{psi}\left(121^{\circ} \mathrm{C}\right)$ for 20 minutes. The sterilized flasks, after cooling, were inoculated with two to three discs of each of the pathogens isolate using sterile cork borer. After plugging, these flasks were incubated at $25^{\circ} \mathrm{C}$ for 7 days. At the time of inoculation, each of the flasks containing inoculum was

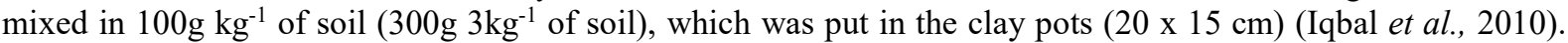
The pathogens were allowed to become established in the infested soil/ for one week before sowing of chickpea 
seeds.

\section{Pathogenicity Test}

Pathogenicity tests were carried out by the technique proposed by Amrutha (2012) and Iqbal et al. (2010). Once the pathogens were isolated and identified, the pathogenicity tests of the pathogens were necessarily for verification, that the fungus was the real cause of the chickpea wilt/root rot diseases or not. In this study, fifteen fungal isolates were isolated from chickpea roots collected from different locations of surveyed areas, which were used for pathogenicity test. Among the 15, particularly, the isolates of Fusarium oxysporum, Fusarium solani and Rhizoctonia bataticola were used for pathogenicity test because of those organisms are the causal agents of wilts and root rots diseases of chickpea.

The same variety of chickpea seeds (local variety) was used for pathogenicity tests in which the pathogens were isolated. The seeds were sown (five seeds per pot) into $20 \times 15 \mathrm{~cm}$ pot size filled with the mixture of vertisol soil, clay and sand at a ratio of 1:1:1, respectively (Figure 7). The soil mixture was sterilized at $121{ }^{\circ} \mathrm{C}$ and 15 psi pressure for $2 \mathrm{hrs}$. In all tests the experiment was carried out in Randomized Complete Block Design (RCBD) with three replications in glass house. This was done by ventilating the glasshouse whenever the temperature rises above the required temperature. The recommended methods of inoculation and doses for the tested pathogens were used (Iqbal et al., 2010; Maitlo et al., 2016).

\section{Inoculation of isolated fungal pathogens Pathogenicity test of Fusarium oxysporum}

The pathogenicity test of Fusarium oxysporum f. sp. ciceri isolates were carried out by the techniques used by

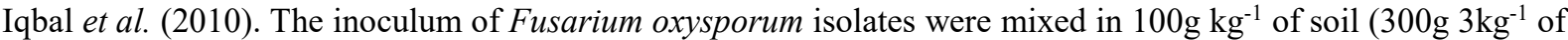
soil/ $100 \mathrm{~g}$ of inoculum mixed with $1 \mathrm{~kg}$ of soil.). Un-inoculated pots were used as control.

\section{Pathogenicity test of Fusarium solani}

Also for pathogenicity test of Fusarium solani similar inoculation methods were used. The inoculum of Fusarium solani isolates were mixed at the rate of $100 \mathrm{~g}$ of inoculum with $1 \mathrm{~kg}$ of soil Iqbal et al. (2010). Uninoculated pots were used as control.

\section{Pathogenicity test of Rhizoctonia bataticola}

The pathogenicity test of Rhizoctonia bataticola isolates were carried out by the procedure used by Amrutha (2012). Then the inoculum of Rhizoctonia bataticola isolates was mixed with sterilized soil at $100 \mathrm{~g} \mathrm{~kg}-1 \mathrm{soil}$ and filled in the pots. Un-inoculated pots were used as control.

\section{Data Assessment}

Identical symptoms that exhibited in field during field survey were developed to those of inoculated plants and morphological characteristics of conidia and mycelia of the fungi in the re-isolated pathogens were confirmed by Koch's postulate. The initial symptoms were recorded based on the symptoms of light yellow, dropping of leaves and dead plants and also final wilting of host after $15^{\text {th }}$ day of inoculation. The plants that exhibit wilt disease symptoms in the surveyed areas were identified by pathogenicity test. The test pathogen was re-isolated to confirm the Koch's postulates.

\section{Evaluation of resistance of chickpea varieties against the identified wilt/root rots causing pathogens under glasshouse conditions}

The evaluation of resistance of chickpea varieties against identified pathogens was conducted in glasshouse in Ambo Plant Protection Research Center (APPRC) during 2017/18. A total of seven promising chickpea varieties (Table 1) evaluated against the isolated wilt and root rots disease causing pathogens (Fusarium oxysporum, Fusarium solani and Rhizoctonia bataticola) (Figure 8). The chickpea varieties were obtained from Debre Zeit Agricultural Research Center (DZARC). The Arerti variety was reported as disease resistant and used as resistant check (DZARC, 2006) and local variety was obtained from the farmer's field of Ambo District and used as a susceptible check. 
Table 1 Details of chickpea varieties, year of released and area adaptation of altitude level

\begin{tabular}{lllll}
\hline No & Varieties & Year of released & Rain fall (mm) & $\begin{array}{l}\text { Area of adaptation altitude level } \\
\text { (m. a. s. 1.) }\end{array}$ \\
\hline 1 & Local variety & & - & - \\
2 & ( susceptible check) & 2004 & $700-1200$ & $1800-2600$ \\
3 & Habru & 2004 & $700-1200$ & $1800-2600$ \\
4 & Chefe & 1999 & $700-1200$ & $1800-2600$ \\
5 & Shasho & 1999 & $700-1200$ & $1800-2600$ \\
6 & Arerti (Resistance check) & 2009 & $600-1200$ & $1600-2400$ \\
7 & Acos dube & 1974 & $700-1100$ & $1800-2300$ \\
\hline
\end{tabular}

Source: (MoARD, 2008; Menale et al., 2009)

\section{Disease Assessment}

Data were collected at 25 days after inoculation based on the reactions of the varieties, where the initial symptom was observed (Haware and Nene, 1980). The disease incidence further classified into 1-9 scale (Iqbal et al., 1993) and disease severity scale classified in to 0-4 scale (Table 2; Haq and Jamil, 1995) and fit into the formula to worke out host reactions. The level of resistance and susceptibility of each varieties was determined by using 1-9 rating scale is given by Iqbal et al. (1993) (Table 3).

\section{Disease incidence}

The incidence of chickpea wilt disease was calculated using the number of infected plants and expressed as a percentage of the total number of plants assessed.

Disease incidence $(\%)=\underset{\text { Total number of plants assessed }}{\text { Number of infected plants }} X 100$

\section{Disease severity}

The severity of the disease was examined visually on the whole plants and recorded as the percentage of plant parts (tissue) affected (percentage of wilt infection of the plant). Disease development on varieties was scored per plant basis using a five point severity scale based on percentage of tissue showing wilt symptoms (Table 3; Haq and Jamil 1995). Then, on the basis of average disease score, the varieties were categorized into reaction types such as resistant, moderately resistant and susceptible of average disease score.

Table 2 Severity scale and its descriptions.

\begin{tabular}{|l|l|}
\hline Scale & Description \\
\hline 0 & $0 \%$ wilted plant \\
\hline 1 & 1 to $20 \%$ wilted plant \\
\hline 2 & 21 to $50 \%$ wilted plant \\
\hline 3 & 51 to $100 \%$ wilted plant \\
\hline 4 & Dead plant (collapse) \\
\hline
\end{tabular}

Source: Haq and Jamil (1995)

Table 3 The scale for disease incidence of infected chickpea varieties to the isolated wilt causing pathogens.

\begin{tabular}{|l|l|l|}
\hline Scale & Percent disease incidence & Reaction \\
\hline 1 & $0-10 \%$ & Highly resistant \\
\hline 3 & $11-20 \%$ & Resistant \\
\hline 5 & $21-30 \%$ & Moderately resistant \\
\hline 7 & $31-50 \%$ & Susceptible \\
\hline 9 & $51-100 \%$ & Highly susceptible \\
\hline
\end{tabular}

Source: Iqbal et al. (1993).

\section{Data analysis}

The incidence and severity data was analysed by using the statistical analysis of SAS software version 9.0 in Randomized Complete Block Design (RCBD). Least significant difference (LSD) was used to separate treatment means $(\mathrm{P}<0.05)$. Also charts using of Excel was drawn and comparison of means was conducted with Fishers' LSD tests at $5 \%$ statistical probability level to examine mean statistical differences among treatments. 


\section{RESULTS AND DISCUSSION}

Isolation of chickpea wilt/root rots causing pathogens

Isolation of the fungi was carried out from wilted chickpea plants which were collected from the surveyed areas of West Shewa zone of Ethiopia. The laboratory results revealed that from 70 wilted plant samples grown in PDA media only 40 samples were developed as a pure cultures and a total of one hundred forty two (142) different fungal cultures were obtained. Based on their colony morphology, mycelial growth, pigmentation and microscopic observations from the total of 142 cultures; 72 were Fusarium oxysporum, 38 were Fusarium solani, 20 were Rhizoctonia bataticola, and 12 were unidentified cultures because they were not sporulated or developed spores.

The frequency of occurrence of Fusarium oxysporum, Fusarium solani and Rhizoctonia bataticola regardless of the districts were 50.7\%, 26.76\% and 14.08\%, respectively (Table 9). Similarly, Nikam et al. (2011) reported that out of the 80 chickpea wilted samples studied, nearly about 65 samples proved the association and frequency of occurrence of $F$. oxysporum $(81.25 \%)$ followed by 10 samples of $R$. bataticola $(12.50 \%)$ and 5 samples of $S$. rolfsii $(6.25 \%)$. Similarly, Eshetu et al., (2015) reported that the presence of $F$. oxysporum was associated with other species of Fusarium solani in culture petriplates. Fusarium solani was shown to be the most common and frequently isolated (73\%) pathogen from infected roots of faba bean, followed by $R$ bataticola $(32.6 \%), F$. oxysporum $(27 \%)$, R. solani $(10.9 \%)$, Ditylenchus dipsaci $(8.7 \%)$ and Alternaria spp. $(2.2 \%)$; the remaining (4.3\%) were unidentified fungi species. Meki et al. (2008) reported that about 30\% yield loss of chickpea is due to chickpea wilts and also who have been reported that $F$. oxysporum was isolated from more than $50 \%$ of the root samples. Merkuz et al. (2011) reported that Fusarium wilt disease was found to be prevalent in almost all the surveyed chickpea-growing areas of Ethiopia. In this study, the affected plant roots when split opened showed discoloration of internal tissues as black. Similarly, Haware et al., (1986) reported that symptoms of chickpea wilts showed discoloration of internal tissues as black and also the presence of $F$. oxysporum was associated with other species of Fusarium solani and other pathogenic root and collar rot soil fungi (F. equiseti, F. culmorum, Sclerotium spp and Rhizoctonia solani) on culture plates.

Similar result was obtained by Azza (2000) the different species of Fusarium were identified viz. F. oxysporum f. sp. ciceri and $F$. solani as a causal agent of chickpea wilt or root rot disease in culture plates. Aghakhani et al. (2009) reported that twenty - three isolates of $R$. bataticola causing dry root rot of chickpea collected from 10 different major chickpea growing states of India were highly variable in their morphological and cultural characters as well as pathogenicity /virulence.

Table 9 List of isolated fungal pathogens and frequency of occurrence on wilted chickpea samples collected from Ambo and Dendi districts during 2017/2018.

\begin{tabular}{lcl}
\hline Fungal Pathogen & Number of cultures* & Frequency of occurrence (\%) \\
\hline Fusarium oxysporum & 72 & 50.7 \\
Fusarium solani. & 38 & 26.76 \\
Rhizoctonia bataticola & 20 & 14.08 \\
Un identified cultures & 12 & 8.45 \\
Total & 142 & $100 \%$ \\
\hline
\end{tabular}

\section{Morphological and cultural characteristics of wilt/root rots pathogens}

In this study, the morphological and cultural characteristics of wilt and root rot pathogens were observed on PDA media culture plates as follows:

The mycelial growth of Fusarium oxysporum isolates were recorded on culture plates as white cottony (Iso4, Iso-5), fluffy (Iso- 1, Iso-2), and partial fluffy on Iso-3. The pigmentations of the the colony color was noticed as white in ( Iso-1, Iso-2, Iso-4 and Iso-5) and grey orange on Iso-3 culture plates (Leslie and Summerell, 2006) (Figs. 11, 15, 17). The septation and macro and micro conidia were observed on all the culture plates (Iso-1, Iso2 , Iso-3, Iso-4, Iso-5). The shape of the micro-conidia was round to oval and the macro-conidia were sickle shaped. The chlamydospores were observed on Iso-1 and Iso-2 culture plates only whereas in other cultures plates the chalamydospores were not noticed (Table 10).

The mycelial growth of Fuarium solani isolates were noticed as velvety on (Iso-1, Iso-2 and Iso-4) and fluffy on Iso-3 and Iso-5 culture plates. The pigmentations of the the colony color was noticed as red on (Iso-1, Iso-3, and Iso-5) light pinkish on (Iso-2) and grey purple on Iso-4 culture plates (Leslie and Summerell, 2006) (Table 10; Figs. 12, 14, 17). The septation and macro and micro conidia were observed on all the culture plates (Iso-1, Iso-2, Iso -3, Iso-4, Iso-5). The shape of the micro-conidia was round to oval and the macro-conidia were slightly curved shape. The chlamydospores were observed on Iso-3 and Iso-4 culture plates only whereas in other cultures plates the chalamydospores were not noticed (Table 10).

The mycelial growth of Rhizoctonia bataticola isolates were noticed fluffy on Iso-2, Iso-4, and Iso-5 culture plates but appressed in Iso-1 and Iso-3 culture plates (Fig. 13). The pigmentations of the the colony color was noticed as black in Iso-1 and Iso-3 culture plates whereas in (Iso-2, Iso-4 and Iso-5) culture plates showed dark 
brown color (Watanabe, 2002; Srinivas, 2016) (Table 10; Fig. 13). The septation, conidia and chalamydospores were not noticed in all culture plates. But the sclerotia were observed in some isolates and shape of sclerotia varied from round, ovoid to irregular. The sclerotia were dark brown to black in color. Thus the fungus under present investigation identified as Rhizoctonia bataticola.

Table 10 Cultural and morphological characteristics of isolates of Fusarium oxysporum, Fusarium solani and Rhizoctonia bataticola

\begin{tabular}{lll}
\hline & Cultural characteristics & Morphological characteristics \\
Isolates & Mycelial growth Pigmentation &
\end{tabular}

\begin{tabular}{|c|c|c|c|c|c|}
\hline \multicolumn{6}{|c|}{ Fusarium oxysporum } \\
\hline & & & Septation & Conidia & Chlamydospore \\
\hline Iso-1 & Fluffy & White & Present & Macro conidia & Present \\
\hline Iso-2 & Fluffy & White & Present & Both & Present \\
\hline Iso-3 & Partial fluffy & Grey orange & Present & Macro conidia & Absent \\
\hline Iso-4 & White cottony & White & Present & Both & Absent \\
\hline Iso-5 & White cottony & White & Present & Both & Absent \\
\hline \multicolumn{3}{|c|}{ Fusarium solani } & Septation & Conidia & Chlamydospore \\
\hline Iso-1 & Velvet & Red & Present & Macro conidia & Absent \\
\hline Iso-2 & Velvet & Light pinkish & Present & Both & Absent \\
\hline Iso-3 & Fluffy & Red & Present & Both & Present \\
\hline Iso-4 & Velvet & Grey purple & Present & Macro conidia & Present \\
\hline Iso-5 & Fluffy & Red & Present & Both & Absent \\
\hline \multicolumn{3}{|c|}{ Rhizoctonia bataticola } & Sclerotia & Conidia & Chlamydospore \\
\hline Iso-1 & Appressed & Black & Absent & - & - \\
\hline Iso-2 & Fluffy & Dark brown & Absent & - & - \\
\hline Iso-3 & Appressed & Black & Present & - & - \\
\hline Iso-4 & Fluffy & Dark brown & Absent & - & - \\
\hline Iso-5 & Fluffy & Dark brown & Absent & $\begin{array}{l}- \\
--\end{array}$ & - \\
\hline
\end{tabular}

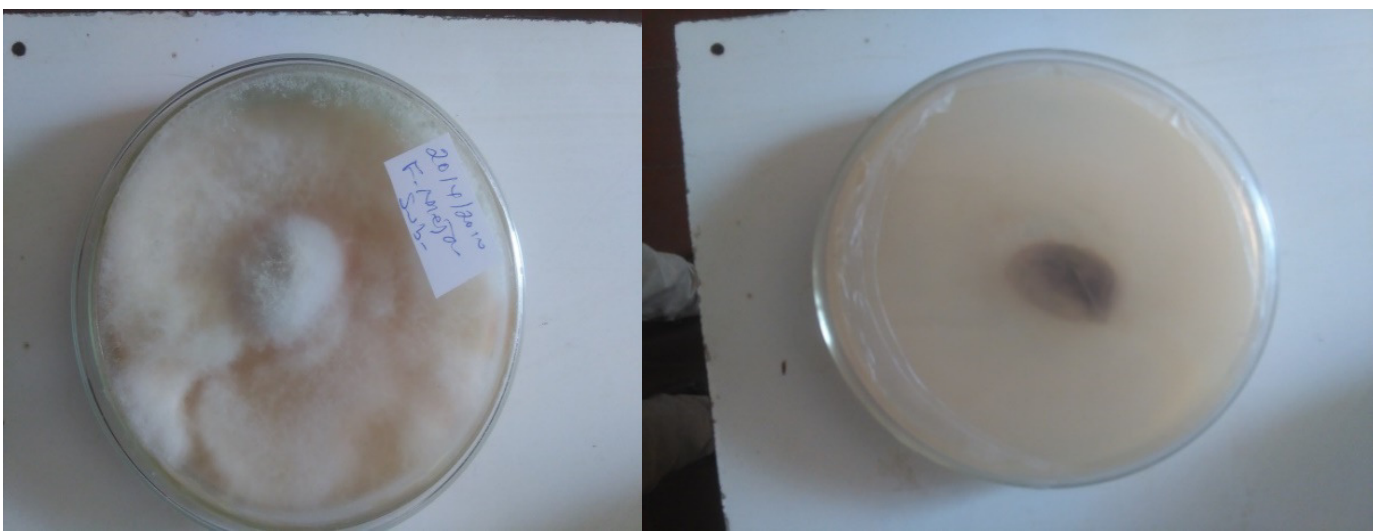

Figure 11 Fusarium oxysporum grown on PDA media culture plates

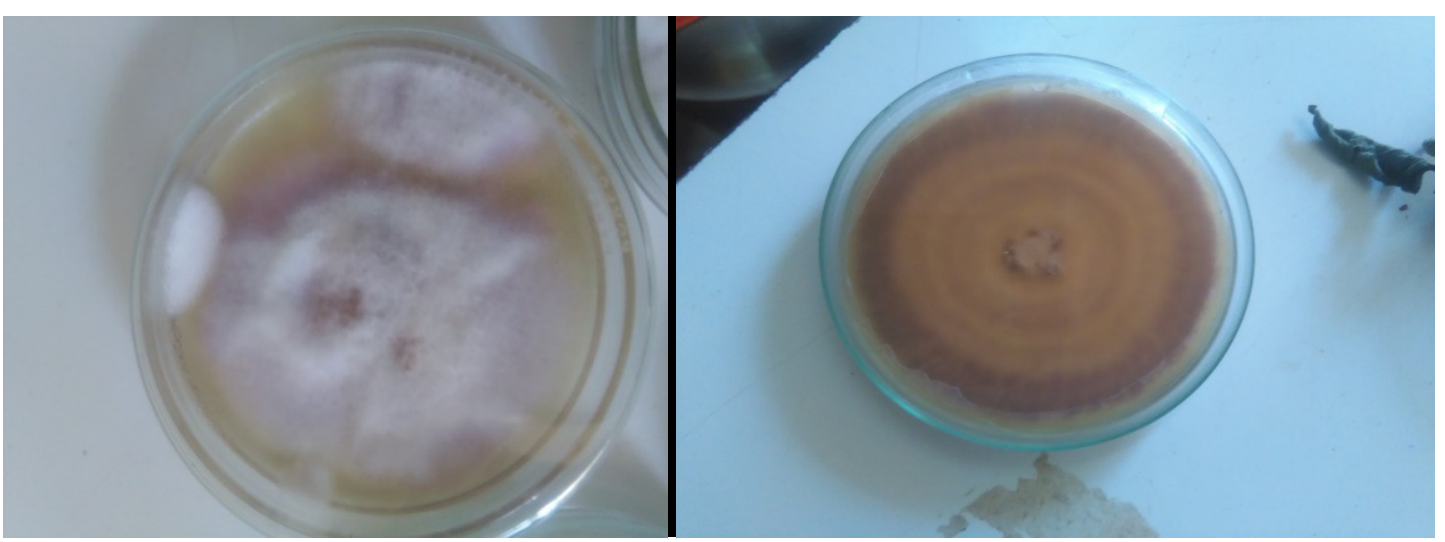

Figure 12 Fusarium solani grown on PDA media culture plates 


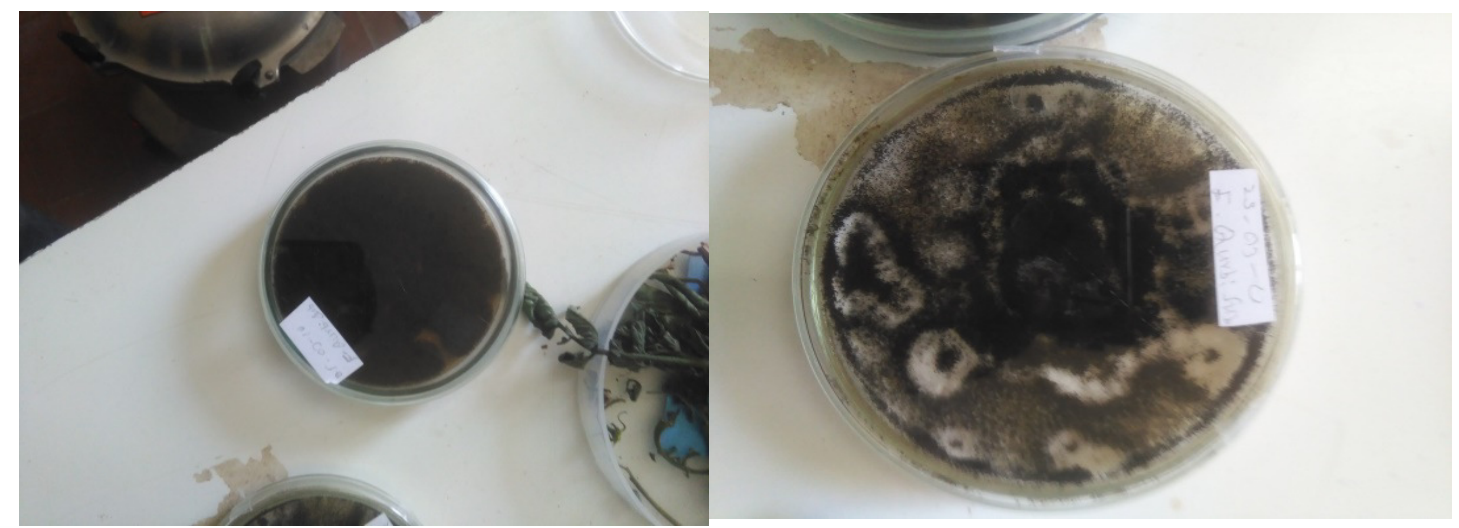

Figure 13 Rhizoctonia bataticola grown on PDA media culture plates

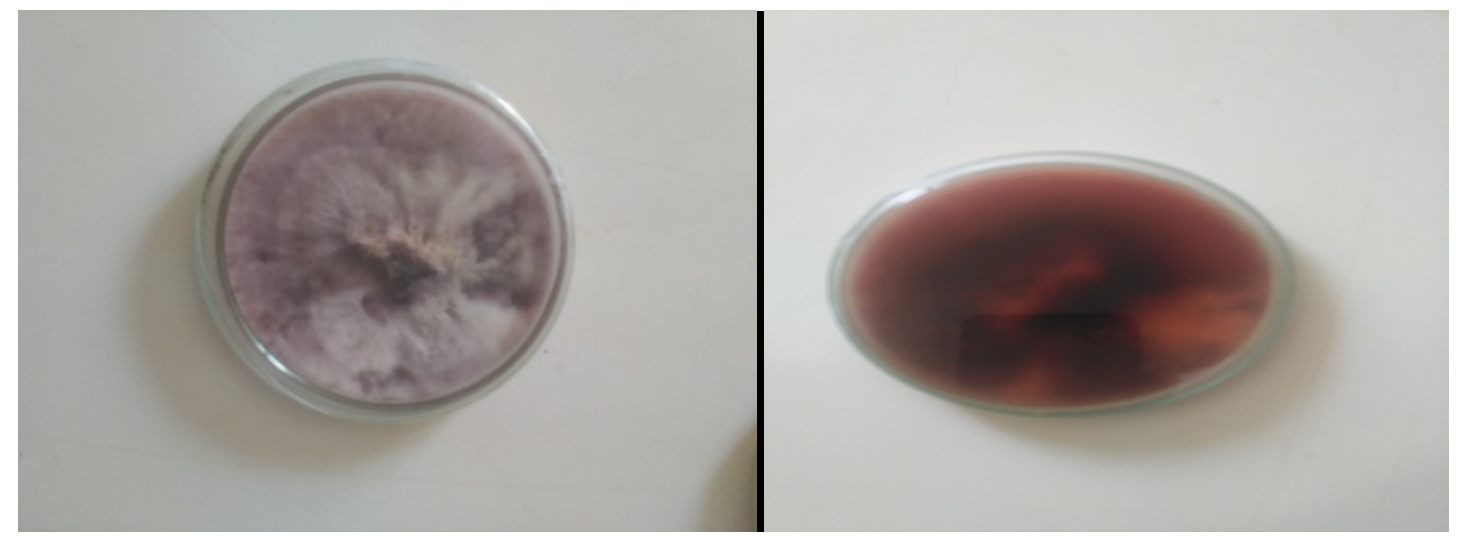

Figure 14 Fusarium solani grown on oat meal agar media

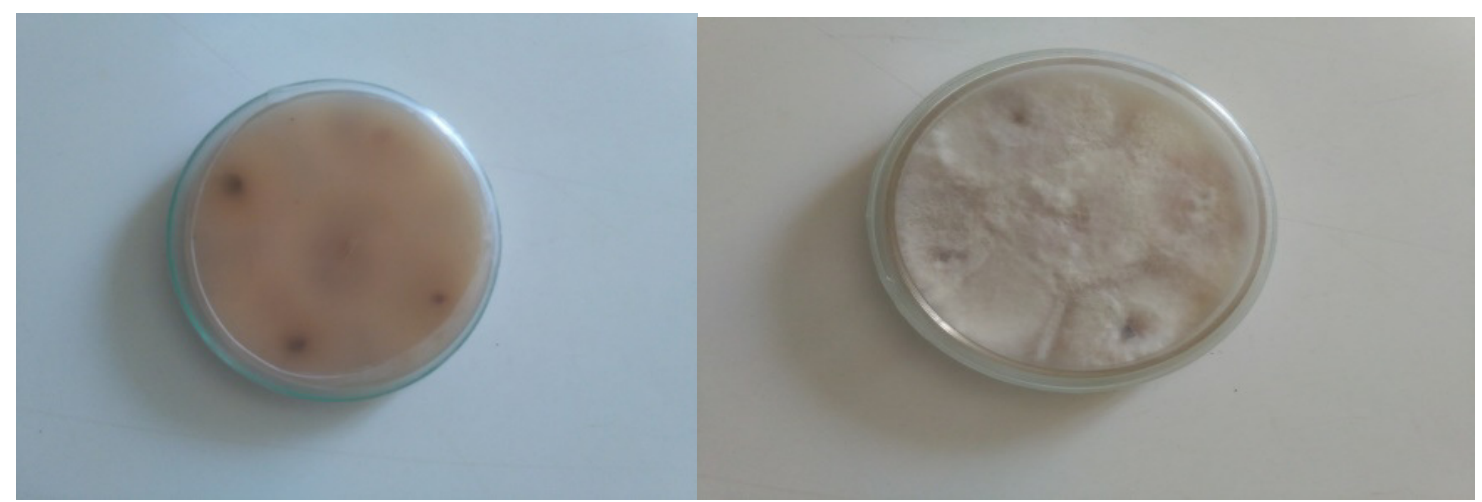

Figure 15 Fusarium oxysporum grown on oat meal agar media

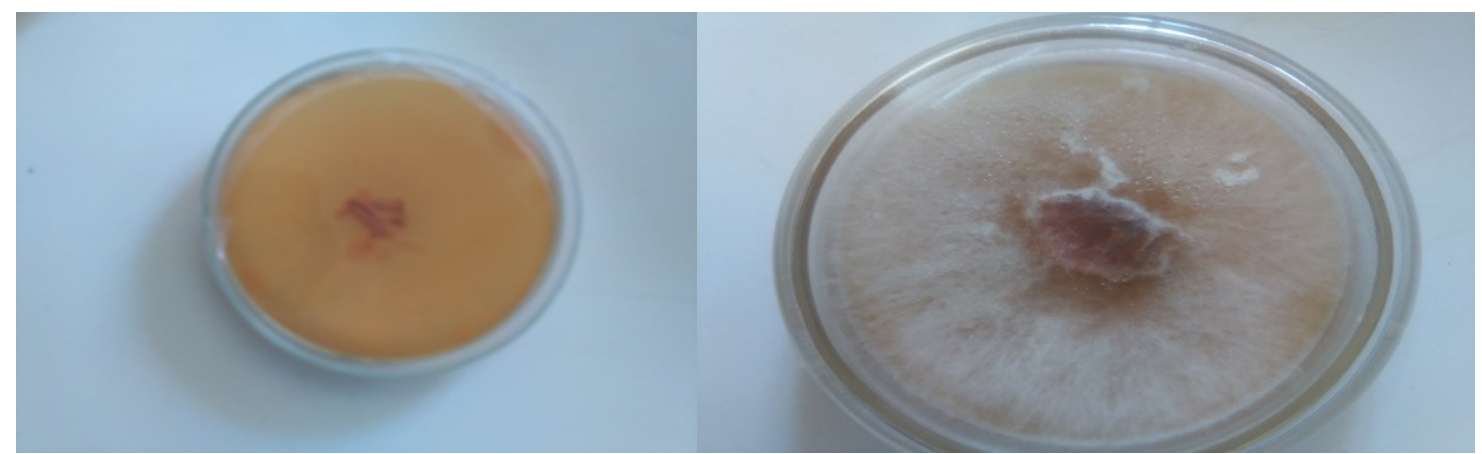

Figure 16 Fusarium oxysporum grown on sabouraud's agar media 


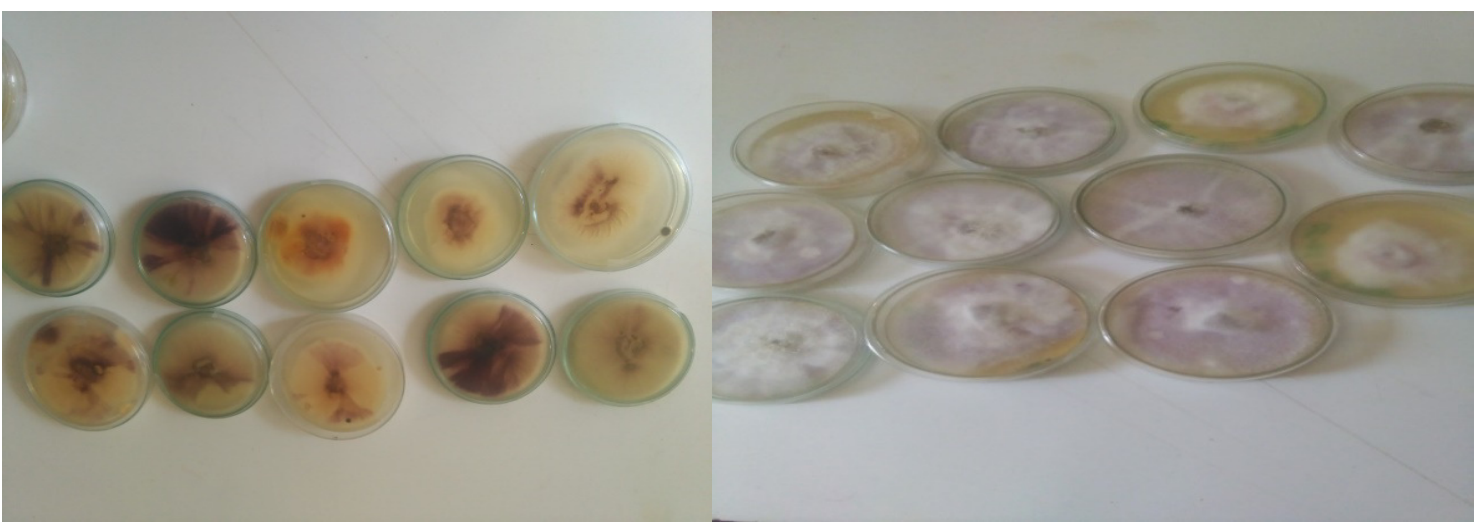

Figure 17 Fusarium solani grown on Sabouraud's agar media

\section{Pathogenicity test}

The reaction of wilt/root rot causal organisms on pathogenecity test is given in tables $11 \& 12$ and Figure 18 . The highest pre- emergence wilt infection, disease incidence and severity was recorded by $F$. oxysporum (Iso-2) isolated from Ambo district followed by F. solani (Iso-3) isolated from Dendi district and R. bataticola (Iso-3) from Ambo district. It is concluded from the results, the isolates, $F$. oxysporum (Iso-2) followed by $F$. solani (Iso-3), and R. bataticola (Iso-3) were the more virulent ones (Table 12). Those virulent isolates showed high disease severity and incidence than the other isolates. The pathogenecity test was confirmed that the tested fungal isolates of Fusarium oxysporum, Fusarium solani and Rhizoctonia bataticola were the causal agents of chickpea wilt in the surveyed areas severly.

Based on this test, F. oxysporum, F. solani, Rhizoctonia bataticola were constantly proved to be pathogenic. This result is in conformity with the earlier reports of Ali et al. (2000) and Hussein (2001). The morphological and cultural characteristics of the F. oxysporum obtained were similar to those reported earlier by Gupta et al. (1986). The symptoms produced during the test of pathogenicity were exactly identical to those described earlier by Westerlund et al. (1974) and Cabrera et al. (1985). Re isolation studies revealed the presence of the same fungus identical to the original one obtained from naturally wilted plants (Figures 18 and 19). The pathogens were re isolated from the artificially inoculated chickpea seedlings showing wilting/root rots symptoms and the cultures obtained were compared with the original cultures and was found to be similar for its morphology and colony characters.

Table 11 Reaction of wilt causing pathogens isolates for Pathogenicity test

\begin{tabular}{cc|cc|cc}
\hline $\begin{array}{c}\text { Fusarium } \\
\text { oxysporum isolates }\end{array}$ & Reaction & $\begin{array}{c}\text { Fusarium } \\
\text { solani isolates }\end{array}$ & Reaction & $\begin{array}{c}\text { Rhizoctonia } \\
\text { bataticola } \\
\text { isolates }\end{array}$ & Reaction \\
\hline Iso-1 & + & Iso-1 & + & Iso-1 & + \\
Iso-2 & + & Iso-2 & + & Iso-2 & + \\
Iso-3 & + & Iso-3 & + & Iso-3 & + \\
Iso-4 & + & Iso-4 & + & Iso-4 & + \\
Iso-5 & + & Iso-5 & + & Iso-5 & + \\
\hline
\end{tabular}

$(+)$ indicate positive reaction or pathogenic 


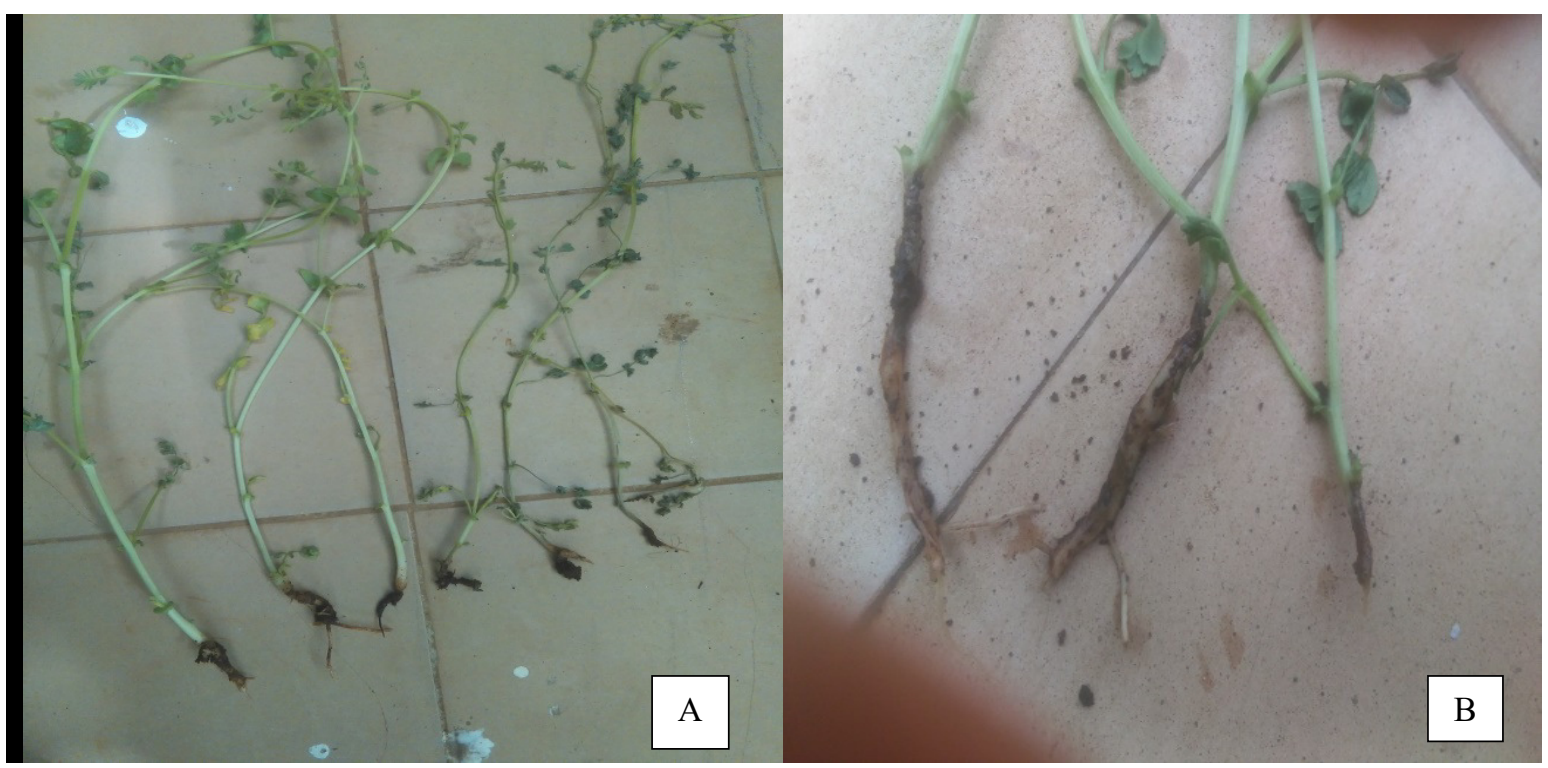

Figure $18 \mathrm{~A}$ and B. Symptoms black root rot caused by isolated pathogens under pot culture conditions in Pathogenicity test.

Table 12 Pathogenicity test of wilt/root rot fungal pathogens which were isolated from chickpea roots in surveyed areas

\begin{tabular}{lcc}
\hline Isolates & Disease incidence \% & Disease severity \% \\
\hline & Fusarium oxysporum & \\
Iso-1 & 32.00 & 20.00 \\
Iso-2 & 68.00 & 51.00 \\
Iso-3 & 32.00 & 17.00 \\
Iso-4 & 40.00 & 27.00 \\
Iso-5 & 32.00 & 15.00 \\
MEAN & 40.80 & 26.00 \\
& Fusarium solani & \\
Iso-1 & 44.00 & 22.00 \\
Iso-2 & 36.00 & 20.00 \\
Iso-3 & 60.00 & 42.00 \\
Iso-4 & 20.00 & 15.00 \\
Iso-5 & 20.00 & 18.00 \\
MEAN & 36.00 & 23.40 \\
& Rhizoctonia bataticola & \\
Iso-1 & 28.00 & 20.00 \\
Iso-2 & 20.00 & 18.00 \\
Iso-3 & 56.00 & 32.80 \\
Iso-4 & 32.00 & 25.00 \\
Iso-5 & 20.00 & 15.00 \\
MEAN & 31.20 & 22.16 \\
\hline
\end{tabular}

\section{Reaction of resistance of chickpea varieties against identified wilt/root rot causing pathogens}

As mentioned before in the pathogenicity test experiments, three isolates from chickpea roots i.e. Fusarium oxysporum (Iso-2) from Ambo district, Fusarium solani (Iso-3) and Rhizoctonia bataticola (Iso-3) from Dendi and Ambo districts, respectively were highly pathogenic and showed higher pre-emergence damping off, mean percent disease incidence and severity. Therefore, they were selected for evaluation test of seven chickpea varieties based on their pathogenic abilities. Reactions of chickpea varieties resistance against isolated wilt causing pathogens were carried out as follows:

\section{Reaction of chickpea varieties resistance against Fusarium oxysporum.}

The statistical analysis revealed that there was highly significant $(\mathrm{P}<0.01)$ variations among varieties in disease incidence and disease severity to Fusarium oxysporum inoculated genotypes (Table 13). The first symptoms was 
appeared at $25^{\text {th }}$ days of incubation periods in all varieties except local and Arerti variety in which they were showed symptoms at $15^{\text {th }}$ and $32^{\text {th }}$ of incubation periods, respectively. The highest disease incidence and disease severity were recorded on local variety (susceptible check) $73.33 \%$ and $52.33 \%$,respectively while, the lowest disease incidence and disease severity were recorded on Arerti variety (resistant check) $20.00 \%$ and $10.33 \%$ and Shasho cultivar $20.00 \%$ and $16.00 \%$ respectively.

Among the varieties tested to this pathogen, Shasho and Arerti varieties showed resistance reaction but Habru variety have disease incidence of $26.66 \%$ and disease severity of $23.00 \%$, it was grouped under moderately resistant (Table 13). Variety Chefe was grouped under susceptible reaction and local and DZ-10-4 varieties were highly susceptible against Fusarium oxysporum. Variety, Acos dube has disease incidence of $40.00 \%$ and severity of $38.00 \%$, it was grouped under susceptible to the disease. The present study results revealed that out of seven varieties evaluated, Shasho and Arerti were resistance to Fusarium oxysporum isolate. This result was similar with the report made by Meki et al. (2008), the varieties Arerti and DZ-10-4 were resistant to all the races of Fusarium oxysporum and prevalent in central Ethiopia, but in the present study results is in deviation with the variety of DZ-10-4, it was found to be highly susceptible.

Ahmad et al. (2007) reported that 139 genotypes obtained from various sources to identify disease resistance against Fusarium wilt under artificially controlled conditions and considerable variations among genotypes were observed at seedling and reproductive stages. Sarwar et al. (2012) tested chickpea lines for potential resistance against Fusarium wilt in wilt sick plot and observed that significant differences for both early and late season wilt incidence. Kirti and Anju (2015) evaluated six genotypes resistance against Fusarium wilt variations were observed between genotypes for their disease reaction at seedling stage and found that 4 genotypes were found to be highly resistant, and two genotypes scored as resistant and moderately resistant response. Khalid (1993) evaluated 122 test lines against Fusarium wilt under field conditions and found 37 of them were resistant, while all the remaining test lines exhibited moderately resistant to highly susceptible reaction. Iftikhar et al., (1997) screened 31 chickpea germplasm lines received from ICARDA, and found that all of them were highly resistant to wilt disease. Bajwa et al. (2000) found that out of 32 genotypes only one line was resistant, 4 lines were tolerant, and 27 were susceptible to highly susceptible against Fusarium wilt. Chaudhry et al. (2006) among 414 varieties/ germplasm accessions evaluated for Fusarium wilt and found that 35 test lines resistant, 208 intermediate, 77 susceptible and 94 highly susceptible. And also he was tested in the next year. Chaudhry et al. (2007) screened 196 chickpea germplasm lines/cultivars for resistance to wilt disease in a wilt sick plot. None of the test line was found immune or highly resistant.

Table 13 Disease Reaction of inoculated chickpea varieties to Fusarium oxysporum in glasshouse conditions.

\begin{tabular}{llcc}
\hline Varieties & PDI & DS \% & Reaction \\
\hline Local & & & HS \\
Habru & $73.33^{\mathrm{A}}$ & $52.33^{\mathrm{A}}$ & $\mathrm{MR}$ \\
Chefe & $26.66^{\mathrm{CD}}$ & $23.00^{\mathrm{D}}$ & $\mathrm{S}$ \\
Shasho & $46.66^{\mathrm{B}}$ & $32.66^{\mathrm{C}}$ & $\mathrm{R}$ \\
Arerti & $20.00^{\mathrm{D}}$ & $16.00^{\mathrm{E}}$ & $\mathrm{R}$ \\
Acos dube & $20.00^{\mathrm{D}}$ & $10.33^{\mathrm{F}}$ & $\mathrm{S}$ \\
DZ-10-4 & $40.00^{\mathrm{BC}}$ & $38.00^{\mathrm{B}}$ & $\mathrm{HS}$ \\
Control & $53.33^{\mathrm{B}}$ & $48.66^{\mathrm{A}}$ & - \\
Mean & $0.00^{\mathrm{E}}$ & $0.00^{\mathrm{G}}$ & \\
CV $(\%)$ & 40.00 & 31.57 & 7.11 \\
LSD $(0.05)$ & 21.82 & 3.93 & \\
\hline
\end{tabular}

Means with the same letters are not significantly different at $\mathrm{P} \leq 0.05$

$\mathrm{CV}=$ Coefficient of variation LSD $=$ Least significance difference at $0.05 \%$

$\mathrm{PDI}=$ percentage Disease incidence $\mathrm{DS}=$ Disease severity $\mathrm{R}=$ Resistance $\mathrm{MR}=$ Moderately Resistance $\mathrm{S}=$ Susceptible HS= Highly Susceptible

Most of the resistant varieties have been found to be susceptible after some years because of breakdown in their resistance and evolution of variability in the pathogen. In the National Chickpea Improvement Program and chickpea varieties having resistance to wilt/root rot have been released for cultivation in Ethiopia (Geletu et al., 1996). Development of plant lines resistant to Fusarium wilt is the most effective approach to the management of the disease includes variety, Arerti and Chefe. Wilt/root rots resistance varieties were evaluated at DZARC for resistance to Fusarium wilt of chickpea on sick plot progressively and continually (DZARC, 2006).

The disease can be controlled with resistant germplasm. However, there are several races of the pathogen that make breeding for resistance difficult. Fortunately, there are genes that confer resistance to the different races (Morgan et al., 2001). Agrios (1997) suggested that resistant varieties are the only practical measure for controlling wilts in the field. Several resistant varieties are available today. Development of plant lines resistant to Fusarium wilts is the most effective approach to the management or eradication of the disease. Breeding of 
resistant lines and identification of DNA markers for resistance to Fusarium wilt has been achieved in chickpea (Sharma et al., 2005). It is important to note that in some cases, resistant plant varieties are only suitable for use against certain Fusarium wilt races (Jiménez-Gasco et al., 2004).

\section{Reaction of chickpea varieties resistance against Fusarium solani}

Similarly to that of Fusarium oxysporum, there was also highly significant differences $(\mathrm{P}<0.01)$ in disease incidence and disease severity on Fusarium solani inoculated varieties. In Fusarium solani inoculated varieties, the first initial symptom was observed at $15^{\text {th }}$ days of incubation on Chefe, Shasho and Acos dube varieties. For the remaining 4 varieties, the symptoms were observed at 25 days of incubation except Arerti similarly with that of Fusarium oxysporum, this variety also showed symptoms at 32 days of incubation. The highest disease incidence was recorded on local variety $(53.33 \%)$ and Acos dube $(39.66 \%)$ and the lowest disease incidence was observed on Arerti (20.00\%). The highest disease severity was recorded on local variety (52.66\%) and Acos dube (39.66\%), and lowest was scored on Arerti (14.33\%). Next to local and Acos dube, variety Chefe disease incidence of $37.33 \%$ followed by varieties, Habru, Shasho and DZ-10-4, the disease incidence of $46.66 \%$, $40.00 \%$ and $40.00 \%$ and disease severity of $33.33 \%, 32.66 \%$ and $31.33 \%$, respectively (Table 14 ).

Among seven varieties inoculated to Fusarium solani, five varieties (Chefe, Habru, Dz-10-4, Shasho and Acos dube) were observed to have susceptible reactions and local variety showed highly susceptible reaction but only Arerti cultivar was resistant. Similarly, Azza, (2004) reported that out of sixteen chickpea cultivars screened for resistance to wilt/root-rot disease in the sick-plot of Fusarium spp, five genotypes were found resistant, with mortality ranging between $9.62 \%$ and $14.86 \%$ whereas two genotypes were moderately resistant with mortality ranging between $17.15 \%$ and $17.88 \%$, and five genotypes were moderately susceptible to the disease with mortality ranging from $20.88 \%$ up to $23.05 \%$. The other four genotypes were highly susceptible where the mortality was more than 25\% (Table 14). (Azza, 2000) reported that when the plants were inoculated with $F$. solani, the disease incidence (mortality rate) was $11.46 \%$ and included under resistant reaction.

Ansar Ahmad, (2010) evaluated that out of 321 tested lines against Fusarium wilt under greenhouse and field conditions the author was investigated that 173 were resistant, 54 were tolerant and 94 were susceptible at seedling stage. Iqbal et al. (2010) also screened 145 chickpea genetic sources of resistance against wilt disease under artificial disease condition and found that 14 genotypes were resistant, 65 tolerant and 66 were susceptible at seedling stage, on the contrary, at reproductive stage, no genotype was resistant, 12 were tolerant and 133 susceptible. Nazir et al. (2012) screen result reported that out 137 chickpea germpalsm lines/cultivars for resistance to against wilt disease in a wilt sick plot none of the test lines were found immune and resistant.

Table 14 Disease incidence, disease severity and reaction of inoculated chickpea varieties to Fusarium solani isolate under glasshouse conditions.

\begin{tabular}{llll}
\hline Varieties & PDI & DS \% & Reaction \\
\hline Local & & & \\
Habru & $53.33^{\mathrm{A}}$ & $52.66^{\mathrm{A}}$ & $\mathrm{HS}$ \\
Chefe & $46.66^{\mathrm{AB}}$ & $33.33^{\mathrm{C}}$ & $\mathrm{S}$ \\
Shasho & $40.00^{\mathrm{B}}$ & $37.33^{\mathrm{B}}$ & $\mathrm{S}$ \\
Arerti & $40.00^{\mathrm{B}}$ & $32.66^{\mathrm{C}}$ & $\mathrm{S}$ \\
Acos dube & $20.00^{\mathrm{C}}$ & $14.33^{\mathrm{D}}$ & $\mathrm{R}$ \\
DZ-10-4 & $46.66^{\mathrm{AB}}$ & $39.66^{\mathrm{B}}$ & $\mathrm{S}$ \\
Control & $40.00^{\mathrm{B}}$ & $31.33^{\mathrm{C}}$ & $\mathrm{S}$ \\
Mean & $0.00^{\mathrm{E}}$ & $0.00^{\mathrm{E}}$ & - \\
CV (\%) & 40.95 & 34.47 & \\
LSD (0.05) & 18.45 & 5.51 & \\
\hline
\end{tabular}

Means with the same letters are not significantly different at $\mathrm{P} \leq 0.05$

$\mathrm{CV}=$ Coefficient of variation, $\mathrm{LSD}=$ Least significance difference at $0.05 \%$

$\mathrm{PDI}=$ percentage Disease incidence $\mathrm{DS}=$ Disease severity $\mathrm{R}=$ Resistance $\mathrm{S}=$ Susceptible

HS= Highly Susceptible.

\section{Reaction of chickpea varieties resistance against Rhizoctonia bataticola}

In Rhizoctonia bataticola inoculated varieties, there was highly significant variations $(\mathrm{P}<0.01)$ recorded among the varieties for the percentage of disease incidence and disease severity. The incubation period for all inoculated varieties were the same which was at 25 days of incubation except Chefe variety, in which the symptom was appeared at 15 days of incubation. The highest disease incidence and disease severity was recorded on Local variety (susceptible check) $(60.00 \%)$ and $(53.66 \%)$, respectively. The lowest disease incidence was recorded on Arerti (20.00\%), Acos dube (20.00\%) and DZ-10-4 (20.00\%). Next to local variety, the highest disease severity was scored on Habru (46.66\%) followed by Shasho (27.66\%) and the lowest was recorded on Arerti (11.66\%), 
DZ-10-4 (14.33\%) and Acos dube (17.667\%) and Chefe (18.00\%) (Table 15). Similarly, with Fusarium solani inoculated varieties, the local variety showed highly susceptible reaction to Rhizoctonia bataticola.

Among the seven, three cultivars, Arerti, Acos dube and DZ-10-4 showed resistant response, two cultivars, Chefe and Shasho showed moderately resistant reaction and Habru showed susceptible reaction to Rhizoctonia bataticola. Similarly, Singh and Mehrotra (1982) reported that cultivars (BG-203, G-543 and Hare Chhole) showed resistant response to $R$. bataticola when grown in infested soil and Reddy et al. (1990) also found resistant to wilt and different root rots of chickpea varieties, J.G.-62 (100\%), Avrodhi and ICCC-48 was (20\%).

Table 15 Reaction of inoculated Chickpea varieties to Rhizoctonia bataticola isolate under glasshouse conditions.

\begin{tabular}{llcc}
\hline Varieties & PDI & DS \% & Reaction \\
\hline Local & & & HS \\
Habru & $60.00^{\mathrm{A}}$ & $53.66^{\mathrm{A}}$ & $\mathrm{S}$ \\
Chefe & $46.66^{\mathrm{B}}$ & $41.66^{\mathrm{B}}$ & $\mathrm{MR}$ \\
Shasho & $26.66^{\mathrm{C}}$ & $18.00^{\mathrm{D}}$ & MR \\
Arerti & $26.66^{\mathrm{C}}$ & $27.66^{\mathrm{C}}$ & $\mathrm{R}$ \\
Acos dube & $20.00^{\mathrm{C}}$ & $11.66^{\mathrm{D}}$ & $\mathrm{R}$ \\
DZ-10-4 & $20.00^{\mathrm{C}}$ & $17.66^{\mathrm{D}}$ & $\mathrm{R}$ \\
Control & $20.00^{\mathrm{D}}$ & $14.33^{\mathrm{D}}$ & - \\
Mean & $0.00^{\mathrm{E}}$ & $0.00^{\mathrm{E}}$ & \\
CV $(\%)$ & 31.42 & 26.38 & 4.68 \\
LSD $(0.05)$ & 24.05 & 6.78 & \\
\hline Means & 13.23 & & \\
\hline
\end{tabular}

Means with the same letters are not significantly different at $\mathrm{P} \leq 0.05$

$\mathrm{CV}=$ Coefficient of variation LSD $=$ Least significance difference at $0.05 \%$

$\mathrm{PDI}=$ percentage Disease incidence $\mathrm{DS}=$ Disease severity $\mathrm{R}=$ Resistance $\mathrm{MR}=$ Moderately Resistance $\mathrm{S}=$ Susceptible HS= Highly Susceptible

Gangwar et al. (2002) were reported that screened 35 chickpea cultivars for resistance to dry root rot caused by Rhizoctonia bataticola in a field experiment. Ten cultivars were resistant whereas 5 genotypes were moderately resistant to dry root rot in a field experiment. Prasad (2006) evaluated 12 cultivars for resistance against dry root rot disease under natural and artificial conditions and found that three of them were lowest mean of disease incidence. Gurha et al. (2007) reported that the eco-friendly management of dry root rot (Rhizoctonia bataticola) and wilt (Fusarium oxysporum) infecting chickpea includes disease resistance plant; cultural control; intercropping and rotation; biological control; chemical control. Also screened chickpea germpalsm lines against dry root rot disease in pot. Use of host plant resistance is the most economical approach for management of dry root in chickpea.

This study indicated that among the fungal pathogens, Fusarium oxysporum is the most prevalent fungal pathogen responsible for wilting in chickpea cultivated fields in West Shewa, Ethiopia and also the root rot disease is widely distributed and as a major problem in most chickpea growing areas of the west Shewa particularly in Ambo and Dendi Districts of the studied area.

Therefore, from the artificial inoculation test, resistance of chickpea varieties to specific isolates could be further deployed for sustainable wilt or root rots management. Germplasm characterization and evaluation can provide useful information to plant breeders, agronomist and other scientists that is essential for better utilization of crop genetic resources. Further, the effective and feasible integrated management options need to be developed on chickpea wilt /root rot diseases in the country.

\section{REFERENCES}

Aghakhani, M. and Dubey, S.C. (2009). Morphological and pathogenic variation among isolates of Rhizoctonia bataticola causing dry root rot of chickpea. Indian Phytopath. 62(2): 183-189.

Ahmad, B., Iqbal S.M. and Haque I. (2007). Evaluation of chickpea germplasm for wilt resistance. Pak. J. Bot., 39: 583-593.

Ali, M.E.K. Inanga, S. and Sugimoto Y. (2000). Sources of resistance to Fusarium wilt of Chickpea in Sudan. Phytopathologia mediterranea. 41: 163-169.

Ansar Ahmad, M., Sheikh M., Iqbal, Najma Ayub., Yasmin Ahmad and Abida Akram. (2010). Identification of resistant sources in chickpea against Fusarium wilt. Pak. J. Bot., 42(1): 417-426.

Armutha, Veena, G. (2012). Studies on integrated management of Rhizoctonia bataticola (Taub.) Butler causing dry root rot of chickpea. 39pp.

Azza Siddig Hussein Abb. (2000). A Study on Wilt/Root-Rot Complex in Chickpea (Cicer arietinum L.) in Shambat Area. Pp. 44.

Bajwa, KM., Khan IA., Alam SS., Ahmad I and Gill MA. (2000). Screening against phytotoxins for resistance to 
Fusarium wilt. Pak. J. Phytopathology, 12:66-70.

Barnett, H. L., \& Hunter, B. B. (1998). Illustrated genera of imperfect fungi (No. Ed. 4). American Phytopathological Society (APS Press).

Cabrera de la colina J, Trapero-casas A, Jimenez-dias RM (1985). Races of Fusarium oxysporum f. sp. ciceris in Andalucia, southern Spain. Int. Chickpea Newslett. 13:24-26.

Chaudhry, M. A., Muhammad, F., \& Afzal, M. (2006). Screening of chickpea germplasm against Fusarium wilt. Journal of Agricultural Research (Pakistan).

Chaudhry, M.A., M.B. Ilyas, F. Muhammad and M.U. Ghazanfar. 2007. Sources of resistance in chickpea germplasm against Fusarium wilt. Myopath, 5(1): 17-21.

CSA (Central Statistical Agency) (2016) Agricultural sample survey report on area and production of crops private peasant holdings, meher season. Pp 2-4. September-December 2014/2015 Volume I, Statistical Bulletin No. 388, Addis Ababa, Ethiopia.

CSA (Central Statistics Authority). (2017). Crop Production Forecast Sample Survey. Report on area and crop production forecast for major grain crops Central Statistical Agency of Ethiopia, Addis Ababa, Ethiopia.

DZARC (Debre Zeit Agricultural Research Center) (2006) Annual Research Report 2005/06. Debre Zeit, Ethiopia.

Food and Agricultural Organization of the United Nations. FAOSTAT. (2016). http://faostat3.fao.org/browse/Q/QC/E. Accessed 30 May 2016.

Gangwar RK Prajapti, RK, Shrivastava, SSL, Kumud Kumar and. Kumar, K. (2002). Resistance in chickpea germplasm against dry root rot. Annuals of Plant Protect. sci. 10(2): 393-394.

Gurha, S. N., Srivastava, M., Trivedi, S., \& Narain, U. (2007). Prospects of Ecofriendly Management of Wilt and Dry Root Rot in Chickpea (Cicer arietinum L.). Ecofriendly Management of Plant Diseases, 215.

Gaur MP, Aravind KJ and Rajeev KV (2012) A review of impact of Genomic technologies on chickpea breeding strategies. Agronomy, 2: 200-203, India.

Geletu B, Million E, Yadeta A. (1996). Improved cultivars and production technology of chickpea in Ethiopia. Debre-Zeit Agricultural Research Center Research Bulletin. No. 2: p. 60.

Gupta O. M., Khare M. N and Kotasthane S. R. (1986). Variability among six isolates of F. oxysporum f.sp ciceris causing vascular wilt of chickpea. Indian Phytopathology, 39: 279-281.

Haq I, Jamil FF. (1995). Comparison of vascular discoloration and growth of Fusarium oxysporum in various segments of chickpea grown in 'wilt sick plot' in Faisalabad, Pakistan. International Chickpea and Pigeon pea Newsletter, 2:30-32.

Haware MP and Nene YL. (1980). Influence of wilt at different growth stages on yield loss of chickpea. Tropical Grain Legume Bulletin, 19:38-40.

Ilyas, M. B., Chaudhry, M. A., Javed, N., Ghazanfar, M. U., \& Khan, M. A. (2007). Sources of resistance in chickpea germplasm against Ascochyta blight. Pak. J. Bot, 39(5), 1843-1847.

Iqbal, M.S., G. Abdul, B. Ahmad, A. Iftkhar, and S. Altaf. (2010). Identification of resistant resources for multiple disease resistance in chickpea. Pakistan J. Phytopathology, 22(2), 89-94.

Iqbal. M.J., K. Iftikhar and M.B. Ilyas. (1993). Evaluation of the chickpea germplasm for resistance against wilt disease. J. Agric. Res. 31(4), 449-453.

Jamil, F. F., Sarwar, M. U. H. A. M. M. A. D., Sarwar, N. I. G. H. A. T., Khan, J. A., Zahid, M. H., Yousaf, S., and Haq, I. (2010). Genotyping with RAPD markers resolves pathotypes diversity in the Ascochyta blight and Fusarium wilt pathogens of chickpea in Pakistan. Pakistan Journal of Botany, 42(2), 1369-1378.

Jiménez-Gasco, M., Milgroom, M. G., \& Jiménez-Díaz, R. M. (2004). Stepwise evolution of races in Fusarium oxysporum f. sp. ciceris inferred from fingerprinting with repetitive DNA sequences. Phytopathology, 94(3), 228-235

Khalid, T. (1993). Screening of chickpea germplasm and fungi toxicants against chickpea wilt disease. M.Sc. Thesis, Dep't. P1 Pathology. Univ. Agric. Faisalabad, Pakistan.

Kirti Rani \& Anju Arora. (2015). Phenotypic screening and molecular characterization of chickpea genotypes against four different races of fusarium wilt. International Journal of Agricultural Science and Research (IJASR) ISSN (P): 2250-0057; ISSN (E): 2321-0087 Vol. 5, Issue 5, Oct 2015, 445-454.

Leslie JF, Summerell BA (2006). The Fusarium Laboratory Manual. V2, Issue: 10, Blackwell Publishing Ltd, Oxford- UK, pp. 101-117.

Maitlo, S. A., Syed, R. N., Rustamani, M. A., Khuhro, R. D., \& Lodhi, A. M. (2016). Influence of Inoculation Methods and Inoculum Levels on the Aggressiveness of Fusarium oxysporum f. sp. ciceris on Chickpea and Plant Growth. Int J Agric Biol, 18, 31-36.

Menale, Kassie, Bekele Shiferaw, Solomon Asfaw., Tsedeke Abate, Geoffrey Muricho, Setotaw Ferede, Million Eshete, and Kebebew Assefa. (2009). Current Situation and Future Outlooks of the Chickpea Sub-sector in Ethiopia. ICRISAT (Nairobi) and EIAR (DebreZeit).

Merkuz A, Seid A, Chemeda F, Sakhuja PK and Getachew A. (2011). Effects of mustard green manure and dried 
plant residue on chickpea wilt (Fusarium oxysporum f.sp. ciceris). Archives of Phytopathology and Plant Protection, 44 (9), $821-831$.

MoARD, 2008. Ministry of Agriculture and Rural Development Crop Variety Development Department: Crop Variety Register. Issue number 11. Addis Ababa, Ethiopia.

Morgan, G.D., Binning, L.K., MacGuidwin, A.E., Connell, T.R. and Schmitt, W.G. (2001). Spatial and temporal distribution of root lesion nematodes. Proceeding of Wisconsin's Annual Potato Meetings. P. 317-334.

Nazir M. A, Khan M. A and Ali S. (2012). Evaluation of national and international chickpea germplasm for resistance against Fusarium wilt (Fusarium oxysporum f. sp. ciceris) in Pakistan. Pak. J. phytopathology, Vol. 24 (2), 149-151.

Nene Y. L and Reddy M. V. (1987). Chickpea diseases and their control. In: The Chickpea, (M.C. Saxena, K.B. Singh, ed.), CABI Publishing, CAB Int., Wallingford, UK, 233-270.

Nigussie, T., Bejiga, G. and Ayalew, M. (1998). Survey and identification of major organisms causing wilt and root rots and their relative importance in chickpea and lentil in Ethiopia on cool-season Food Legumes and Cereals. Regional Networks Annual Report 1997/98: Cairo, Egypt.

Prasad R. (2006). Textbook of Field Crops Production, 3rd Edn., Directorate of Information and Publication of Agriculture, Indian Council of Agricultural Research, Krishi Anusandhan Bhavan, Pusa, New Delhi 110012, pp. 343.

Sarwar, N., Akhtar, K.P., Shah, T.M. and Atta, B.M. (2012). Evaluation of chickpea advance genotypes against Blight and wilt diseases under field conditions. International J. of Agriculture and Biology, 14: 993-996.

Serraj, R., Bidinger, F. R., Chauhan, Y. S., Seetharama, N., Nigam, S. N., \& Saxena, N. P. (2003). Management of drought in ICRISAT cereal and legume mandate crops. Water Productivity in Agriculture: Limits and Opportunities for improvement, CABI Publishing, Wallingford, UK, 127-144.

Sharma KD, Chen W and Muehlbauer, FJ. (2005). Genetics of chickpea resistance to five races of Fusarium wilt and a concise set of race differentials for $F$. oxysporum f. sp. ciceris. Plant Disease. 89:385-390.

Shivendra Pathak. (2016). Pathogenic Variability of Wilt Disease of Chickpea in Vindhyan Plateau. A Journal of Multidisciplinary Advance Research, Vol.5, No. 1, 84- 89.

Srinivas P. (2016). Studies on dry root rot [Rhizoctonia bataticola (Taub.) Butler] of chickpea (Cicer arietinum L.). PhD. Dissertation. Department of plant Pathology College of agriculture Rajendranagar, Hyderabad500030 Professor jayashankar telangana state agricultural university. pp. 68.

Watanabe T. (2002). Pictorial atlas of soil and seed fungi: morphologies of cultured fungi and key to species. 2 nd Ed. Lewis Publishers, CRC PRESS. Florida, pp. 270-276.

Westerlund J, Campbell RN, Kimble KA (1974). Fungal root rots and wilt of chickpea in California. Phytopathology 64:432-436. 